Conjunction in R.A. Oct. 12, 1605 , at oh. $3 \mathrm{Im}$. 445.G.M.T.

R.A. $\quad \ldots \quad \ldots . \quad \ldots \quad 197^{\circ} 4 \mathbf{I}^{\prime} \quad 5 \mathbf{I}^{\prime \prime}$

Moon's hourly motion in R.A. $\quad \ldots \quad \ldots \quad \ldots \quad 35 \quad 37$

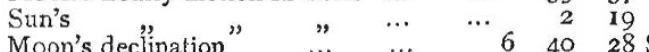

7 75 r $33 \mathrm{~S}$

Moon's bourly motion in Declination ... $\quad$ Io $50 \mathrm{~S}$.

Sun's " " $\quad, \quad \ldots \quad \ldots . \quad 0 \quad 56 \mathrm{~S}$.

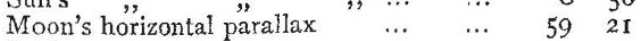

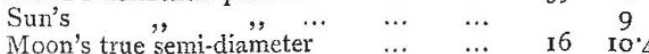

$\begin{array}{llllllr}\text { Sun's } \quad, \quad \ldots & \ldots & \ldots & \text { 16 } & 30^{\circ}\end{array}$

The sidereal time at Greenwich mean noon Oct. I2 was 13 h. $24 \mathrm{~m}$. 10'9s., and the equation of time r $3 \mathrm{~m} .29 \mathrm{~s}$. additive to mean time. The eclipse would be total and central with the sun on the meridian, in longitude $11^{\circ} 18^{\prime}$ W., and latitude $52^{\circ} 26^{\prime} \mathrm{N}$. For Naples, a direct calculation gives a total eclipse, the sun at an altitude of $31^{\circ}$. Beginning of totality at $2 \mathrm{~h}$. I $8 \mathrm{~m}$. I $8 \mathrm{~s}$, , ending at $2 \mathrm{~h}$. I gm. 28 s., mean time at Naples, or duration Im. IOs., which appears to correspond fairly with Kepler's statement that the sun was "covered for a short time" only.

The Minor Planets.-M. Stephan, Director of the Observatory at Marseilles, announces the discovery of another small planet by M. Borelly, on December $I$. Right ascension at midnight, $65^{\circ} 31^{\prime}$; north polar distance, $66^{\circ} 2^{\prime}$; motion towards north-east, thirteenth magnitude. Supposing ail the recently detected minor planets to be new, this will be No. 157. The last circular of the "Berliner Astronomisches Jahrbuch," however, has a suggestion by Prof. Tietjen that No. 152 , discovered by M. Paul Henry at Paris on November 2, may prove to be the same planet which was found by M. Borelly, 1868 , May 29, and which received the name Dike. No. 152 passed the ascending node soon after noon on November 3 , the geocentric longitude at the time being $41^{\circ} 54^{\prime}$, and it was not far from opposition, which is so far favourable to the supposition of identity with Dike, with ascending nore in $4 \mathrm{I}^{\circ} 5 \mathrm{O}^{\prime}$ according to the most probable orbit that could be obtained from the short course of observations in 1868 . Dike was estimated of thirteenth magnitude, yet in 1868 was observed within $10^{\circ}$ from perihelion; in ascending node the planet would be less than $29^{\circ}$ from aphelion ; No. 152 is called eleventh magnitude, a difference, considering the respective orbital positions, which is adverse to identity. The unfavourable weather has prevented observations sufficient for a proper calculation of elements for No. 152. Should this planet prove to be identical with No. 99 (Dike), the numbers from 153 onwards will of course require to be diminished by one, and the actual number of small planets, including $M$. Borelly's late discovery, will stand at 156 .

\section{THE MAMMALS OF YARKAND*}

${ }^{\top} \mathrm{HE}$ unfortunate death of the lamented naturalist, Stoliczka-one of the most promising members of the Indian Geological Survey - must be fresh in the memory of many of our readers. After a successful campaign in Yarkand in company with Sir D. Forsyth's late expedition, he did not live to return to India, but perished of exhaustion amongst the snows of the Himalayas. We are pleased to hear that his Indian friends have undertaken the preparation of a work intended as a memorial of him, which will embrace an account of the extensive collections of natural history amassed during his last journeys. Mr. W. T. Blanford has just issued a preparatory list of the mammals of which specimens were obtained in Yarkand and the adjoining countries. They are referable to forty-two species, mostly belonging to groups characteristic of the elevated districts of the Palæarctic

* "List of Mammalia collected by the late Dr. Stoliczka when attached to the Embassy under Sir D. Forsyth, in Kashmir, Ladák. Eastern Turkesta, and Wakhau, with descriptions of new species." By W. T. Blanford, F.R.S., F.Z.S. (Journ. As. Soc. Bengal, vol, xliv. D. To5, et seqq.) region. No new types were discovered, but amongst the novelties are species of Field-voles, Hares, and Pikas (Lagomys), all very distinctive of the regions traversed by the expedition, and adding largely to our knowledge of the fauna of Western Tibet and Eastern Turkestan. The larger mammals were originally better represented, but after Dr. Stoliczka's death, many specimens appear to have been removed from the collection. Of a fine series of twenty-two wild sheep from Kashgar, only eleven are now left, and not one of these has fine horns. Moreover there remain skeletons of wild sheep and ibex in the collection, of which the heads have entirely disappeared. Mr. Godwin Austen has invited public attention to these unpleasant facts in another column of this journal. One would have supposed that in the case of a naturalist thus perishing in the performance of his arduous duties, no pains could have been too great to protect the specimens in procuring which he had sacrificed his life. On the contrary, however, advantage appears to have been taken of his untimely death to rob his collection of the choicest specimens. We can orly trust that, attention having been called io the fact, restitution will be made, and the missing heads and Lorns promptly restored to the mutilated specimens now deposited in the Imperial Musenm at Calcutta.

\section{ARCHAEOLOGICAL RESEARCHES IN KEN. TUCKY AND INDIANA}

$N$ January last Mr. Putnam laid before the Society of 1 Natural History of Boston, U.S., an extended account of his recent archæological researches in Kentucky and Indiana, in which he had examined several rock-shelters, caves, mounds, and circular graves. He called attention to the numerous ancient fortifications in the Ohio valley, and gave a description of two which he had visited in Indiana. These fortifications are generally earthworks, many of them of great extent; but there have been several discovered in which immense walls of stone have been used, extending in one case to several hundred feet in length, and to nearly ten feet in height; whilst in another instance a wall about seventy-five feet in height had been erected to fill a gap in the otherwise nearly precipitous natural wall. The stones of these walls were simply laid, one overlapping another, so as to break joints, without cement of any kind. Mr. Putnam exhibited to the meeting a number of human skulls and other bones found under various conditions, and pointed out that while the skulls of the New England Indians were long and narrow and belonged to the dolichocephati, those from the mounds, the circular graves, the stone graves, and the caves were of the short, broad and high type, or the brachicephali. In the caves, however, there were two, if not three, classes of burials, and at least two wellmarked forms of skull. The skulls he found in graves protected with slabs of stone were all of a form very closely resembling the high, short and broad crania of the mound builders; those of the numerous skeletons from the caves were characterised by the marked depression of the frontal bone and the equally marked concavity on the anterior part of the parietals; and the skulls from the circular graves were distinguished from the others by their decided width and shortness, and the more vertical occipital portion.

A series of shin-bones was also exhibited to show the various degrees of flattening, and to confirm the opinion of Mr. Busk and others that platycnemism cannot be taken as an important race character.

Of a number of circular graves which formerly existed on a hill near Glasgow, one, having escaped the plough, had been carefully opened. It was a circle about four feet in diamêter, and had been dug to a depth of three feet, where a floor had been formed with pieces of shale brought from a distance of about a quarter of a mile 